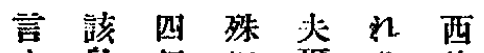

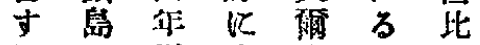
比紧 58 利

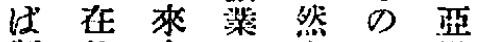

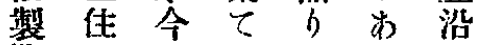

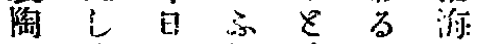

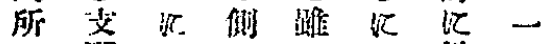

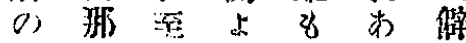

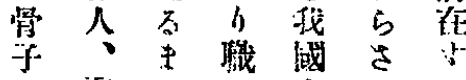

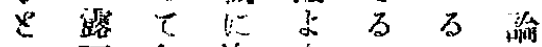

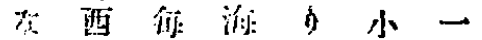

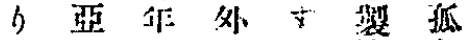
中人 $\cdots$

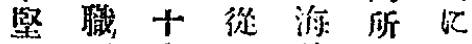
8 工名方利同

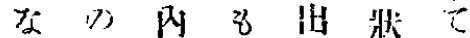
b任外 $\because$ 碇焦

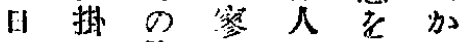

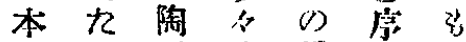

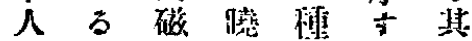

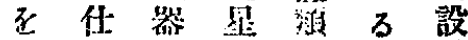

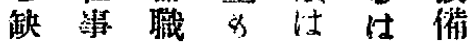

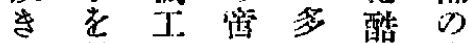

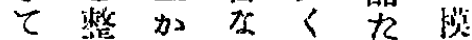

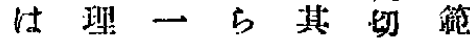

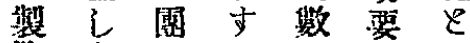

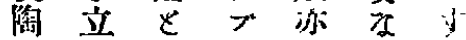

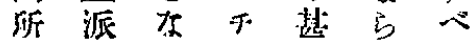
D) b十支尔

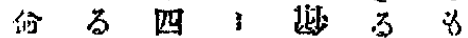

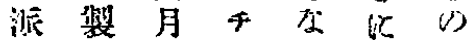

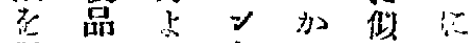

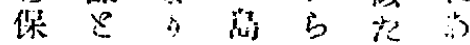

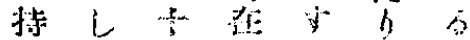
等

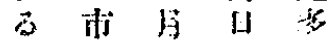

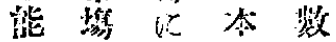

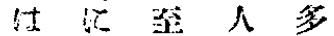
翟 合

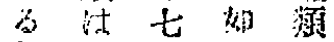
组る 方

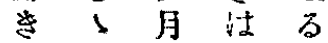
重齐间 成出 要得只干稼 な世㱔入人 万人造面中

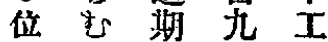
置換中十觜

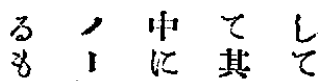
D 公投适 低 1 且 度 地 外总る 艺 に は 化其拎

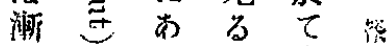
次必b泣 挠 他 落 減 O) $\quad$ \& 40

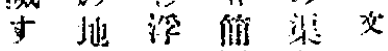

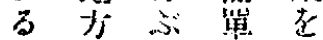

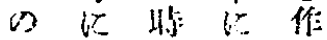
傾 8 : 1

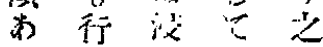

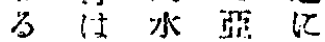

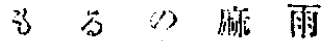
味来水

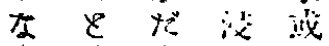

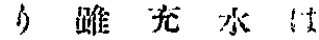
未地分㙈 来地谷多 (5) ह 地 嵌

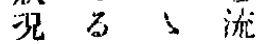
上 澄 落 万

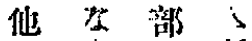
化 b 索縓 方点 万椾

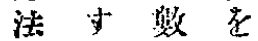
(露 本 连

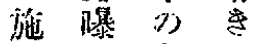
y 法 被 今 杜案比 点 很 成 8 霓 $)$ $\therefore$ 陌 悎

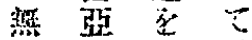

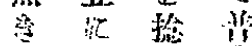

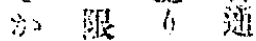
政 $\Rightarrow 2$;

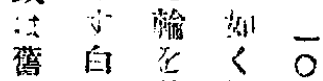
承 11 作: 证 D) 義 万水

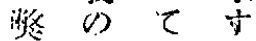
臽 ר文师

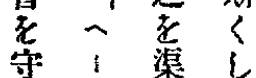




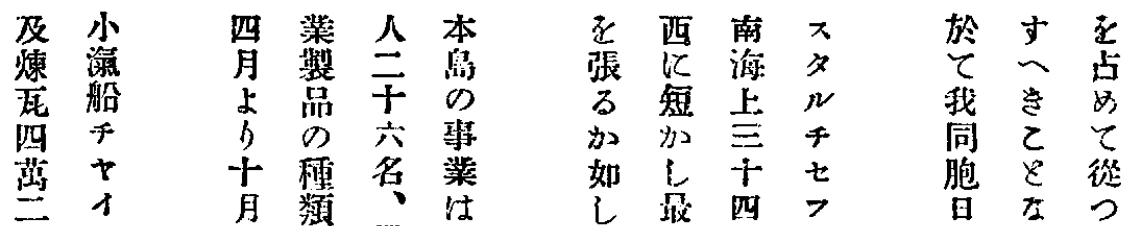

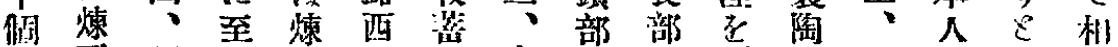

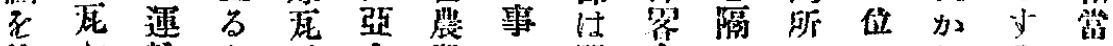

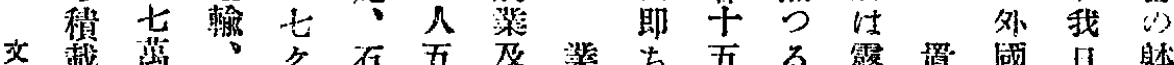

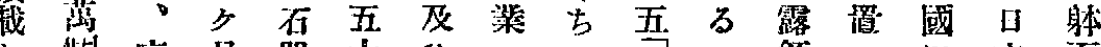
乙䛧艾月器士

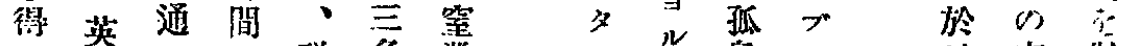
几吉磁名潘 翊外器合等 運柇《部基

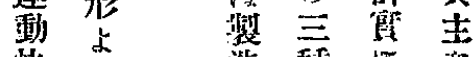

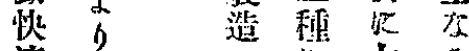

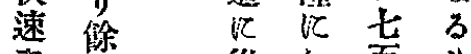

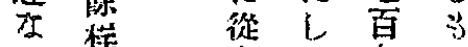
笑策乙元 \%

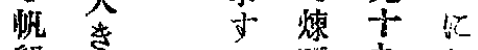

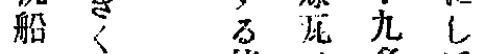

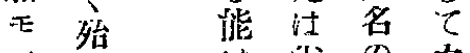

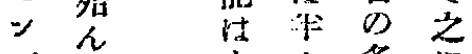

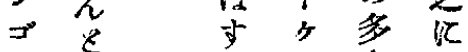

3 年委农

基

应害居全

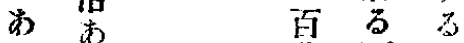

b o 政

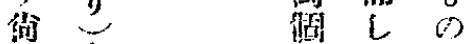

此频

祜

敖

繢

i)

茷焉

欮

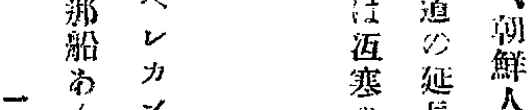

č

製稻

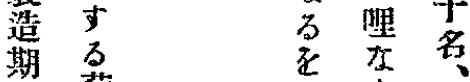

茧

絕 船

知

留 正

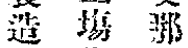

小

灌被 共

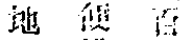

方 锌

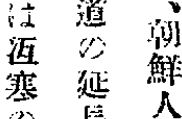

地喜管

等票吉

乙䋹本

次舄舟

$F \times \mathbb{T}$

七 l

7 篦舟

山我 $\%$

行望鼠

绳 $=$ 比

气里 1 在

全晨儿b

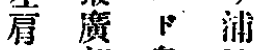

济岛涪

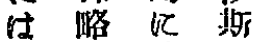

圭五箖德

不 当 渄

计窥保

る栔方

歰江机

陶䄉管

沗逶り

の き 解

一外 酥

般践方

更得

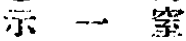

尘籍

儿 製上

加陶幾

雼 所 分

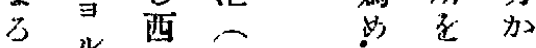

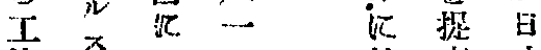

㷪

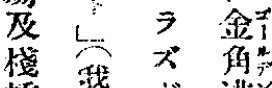

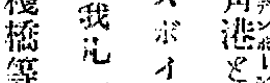

㓡里 至

寸齐”蒜

變鄚

一留

其焉海

状 地 參

恰槜威

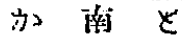

8 北䊈

蛟飞士

龍 長

外來 朴

小つの

$5 \tau$ 曧

端

篮

下棹

i) 安部

解

㩆?

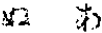

32

i)

少 國

留

江

臂東東

萁篇

-

面㿆 
煭至般し析て 何食步留て西

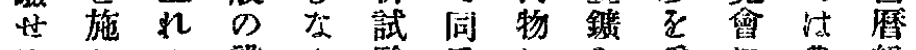

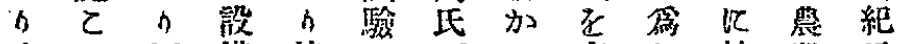

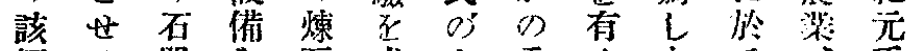

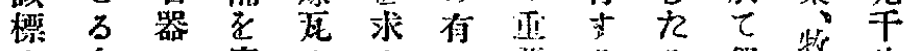

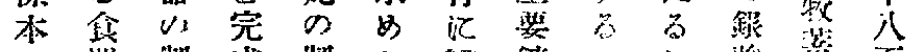

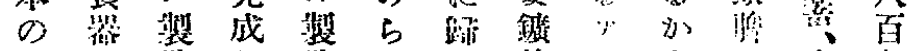

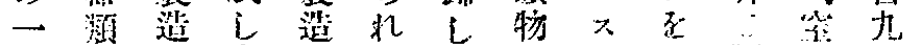

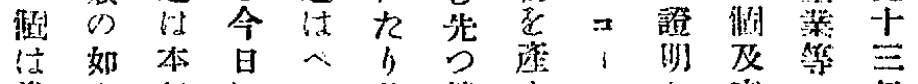

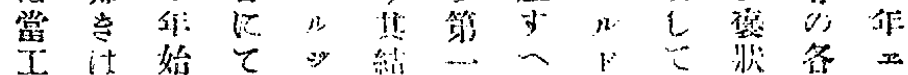
场 永

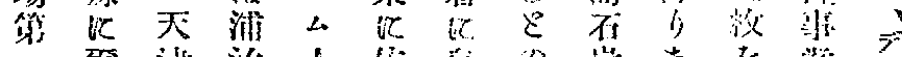

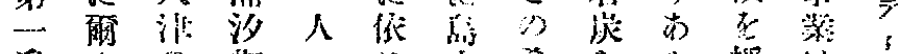

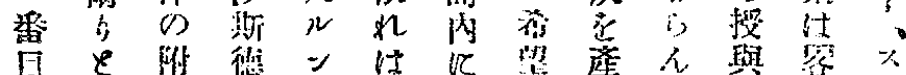

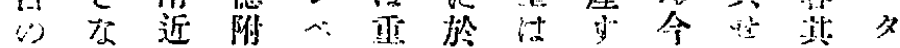

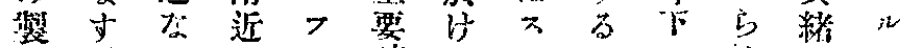

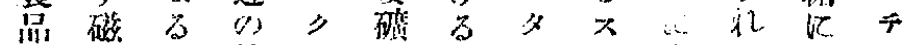

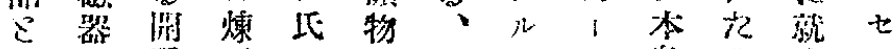

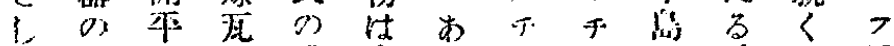

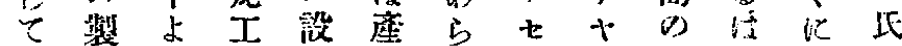

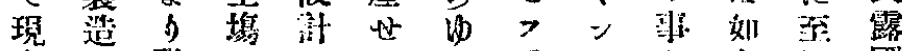

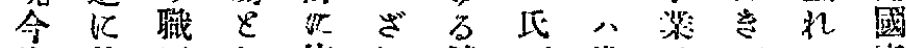

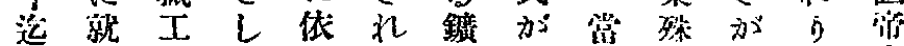

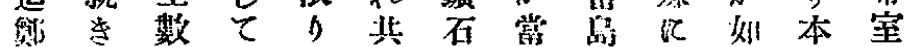

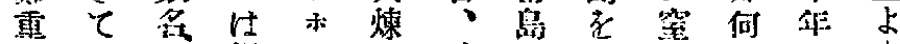

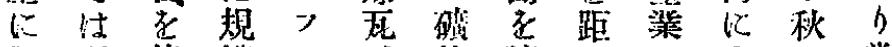

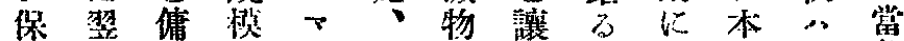

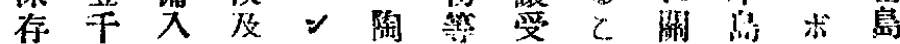

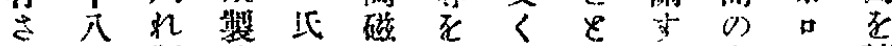

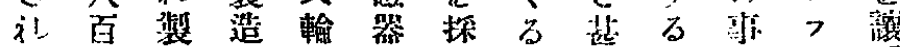

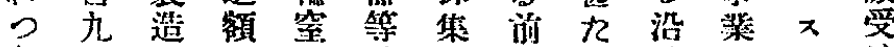

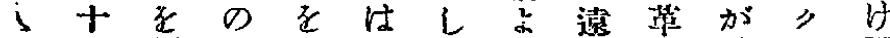

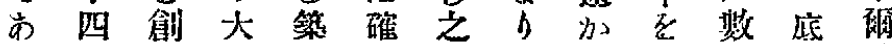

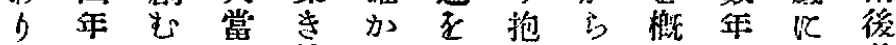

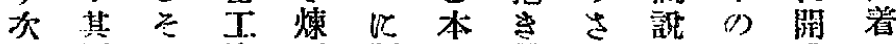
乙 原

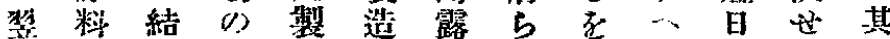

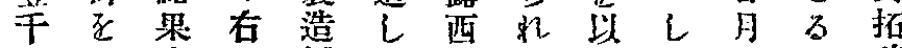

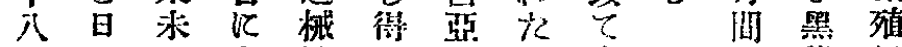

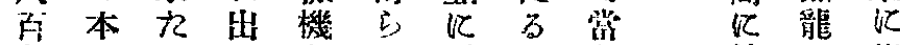

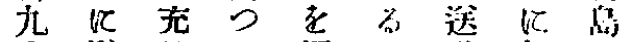

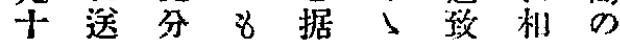
五引打 年之ら在方込之在き

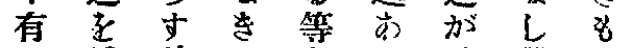
田試釉飞各 $引$ 分繼亦

於 江 從

乙 泭: 整

彭州 L

足 晸 現

D I 今 進榑灯

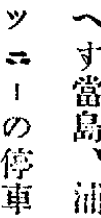

理境 沙 埌 《 淨 沿 邀 德 生

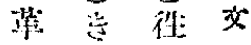
郵 後 侹 ᄂ 焉 䈣

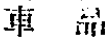
《 大 尷 捬: 搬 装范 政 酸 港了 ᄂ 조 $=$ 刑 $\Rightarrow$ 壮 $\therefore$ 交

ン通

化 非

出 常 $\checkmark \pi$ 維 不

冰 便 雾 晋 蛋 浦 莎 洺 寸 排 丸 德 v 本

奛 海 車三 薘记 寸 戠 F ت゙ p 
望 本

具島

万磁

生 器

免

加 製

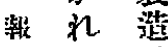

e

創

所

次代 O

ᄂ 炲

$\because \$$

流

y 2 b

8 镀

纸

旒 日

留

本老

狇 整

管 入

權 让

䑀

管

些 部

猋 分

5 壮

椋

ప H

次占

( )

故 L

K

其

留

造 以

法 $\tau$

の 製

灲 造

一法

三

單 自

证 5

型 有

穛

要 風

学
の裴やに胡るす有のる十九口

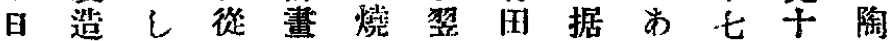

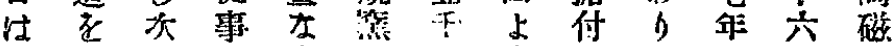

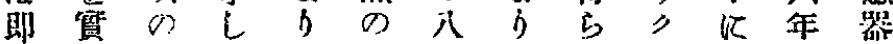

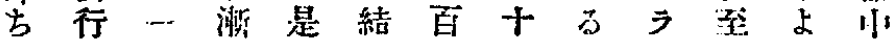

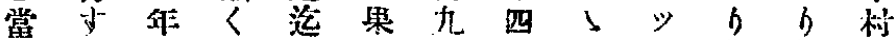

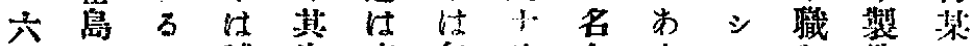

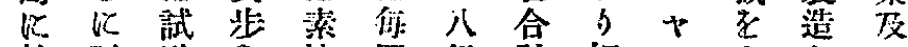

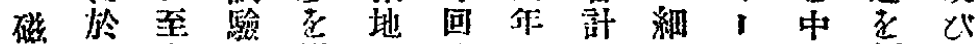

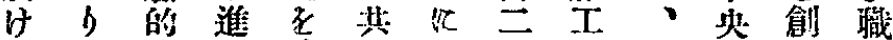

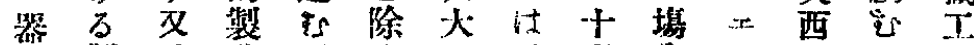

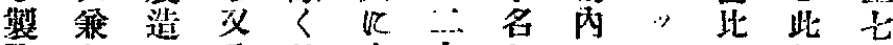

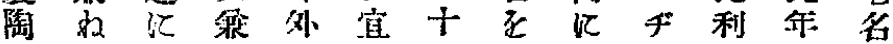

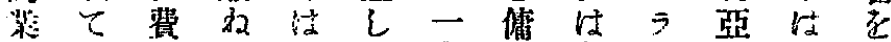

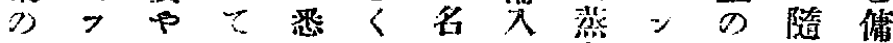
根 $\%$ L $匚$ 中

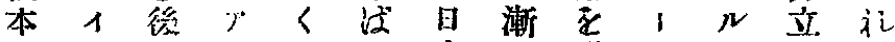

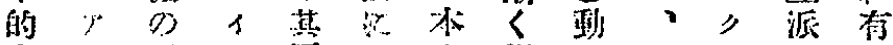
方 $ン$ 三丨原し人規力八ッ田

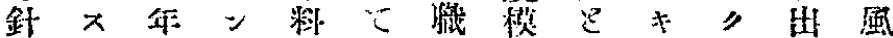

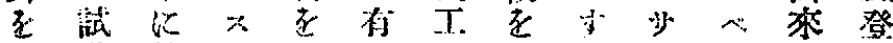
樹驗 於

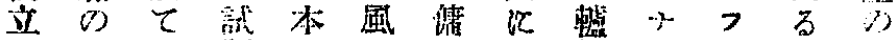

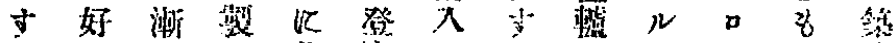

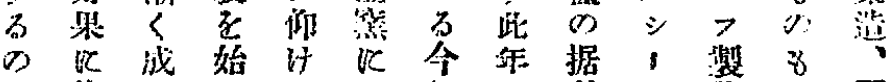

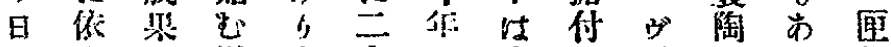

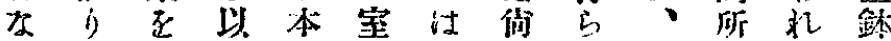

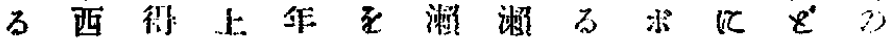

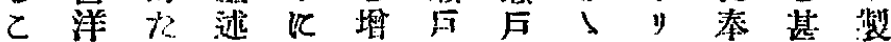

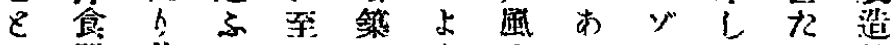

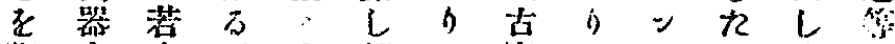

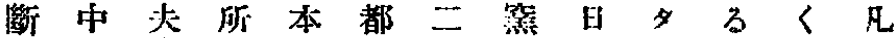

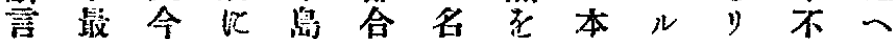

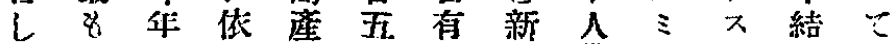

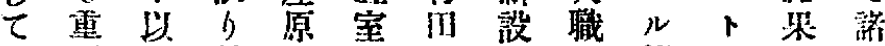

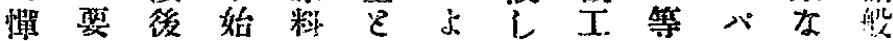

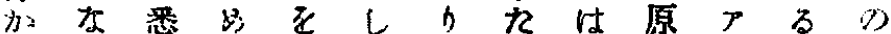
らるをの雨爽十れ其料 朒く

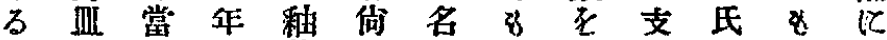

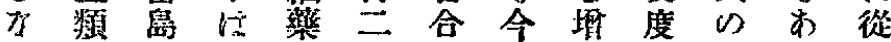

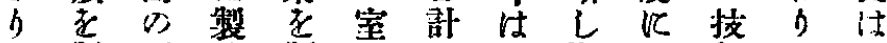

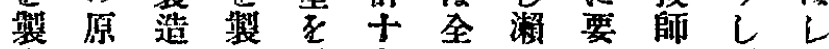

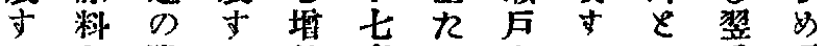
るる凖る筑名くなるし 千翌

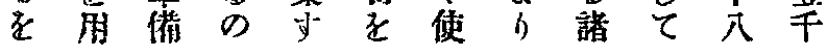
得员江試る佛角六機來帛八

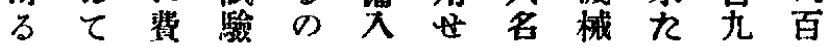




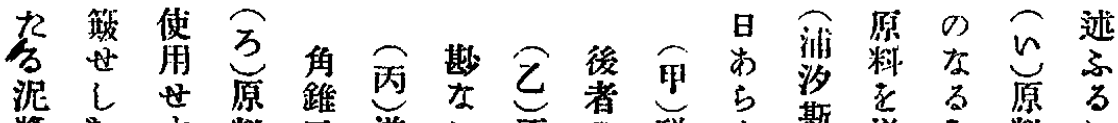

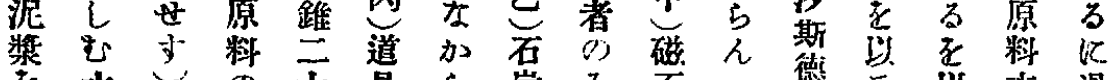

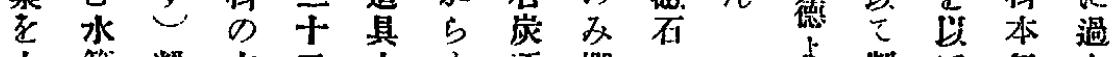

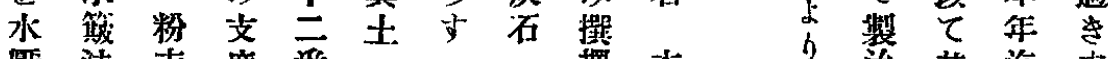

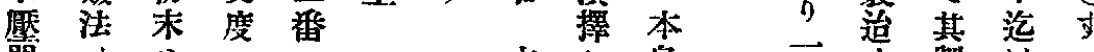
器單 て 純 め㘯

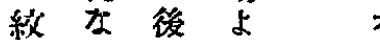
b 30 a 細 水 $\neq$ 探

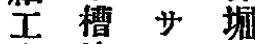
㷪 沈 定 $\% 3$ 造法磁 る れ 1 子 ஜ ヴ 地 今 $\frac{k}{r} \frac{1}{k}$ 年 篩 准

以 别 積

後 L

生份置

長 粗

路 分之

沈杜要

定 $末$ x

法 9 \%

にゾ チ

改

正

寸

उ $\leqslant 1$

篇儿泟

貝江持

下

新白

筑磨引

不水

b 籍 シ

斯 筧

<

ᄂ 送

$\tau$ 餘

得 水

y $\quad$ 的 西

又附陚监

3 近用よ

兵世名

小る夕洨

b)

產

社

率

黄

色

の

粘

$\pm$

k

L

$\tau$

碍

石

の

粗

粘

含

थ

と

多

耐

火

度

せ

1

3゙不

$n$

氏

標

準
万染孪

1 白

下焦

$+$

-

よ

b

策

鼠

色播

K

L

數

D

白

線

क

b

鐵

禁

1. 筑

及 壤

盍世

酸

v

溶

解

物

甚

Fi
ᄂ

象

在

以

$\tau$

$\theta$

柆

b

K

芸

貺

守

る

is

0

क

$b$

㩆

芆

8

()

क

b)

本

年 $\because$ の 法 地

$\exists$ 方惊

儿釬惯 管

大 $\mathbb{x}$

卜茫不磁

文 具

隔其な

隔試る 解

己 验 \&

小机る

b) 從

購 事云外

入 2 蛙

艘さ舴

万光及

等 如可 匣

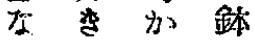

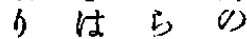

目畧

砂完 然 料

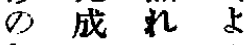

则 $i \varepsilon$ i

近 8 目

立き本砂

㛬无年に

加b 始 至

万潧 める

王小汽

本土 悉

島は凡と

産明心

の) 年 $て$ 日

8 當本

() b 島

要 $=$ 或

用 $\exists$ 仕輸

天 其入

街 不附

る 3 近

D
啹 文 


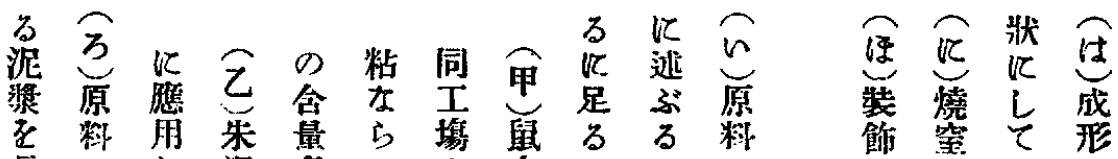

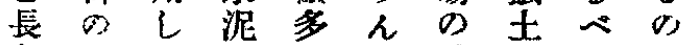

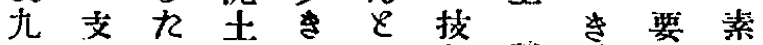

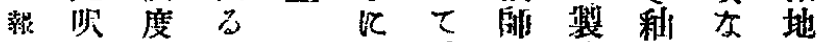
() 流 滤 $\varepsilon$ 來 $b$ 藤 本

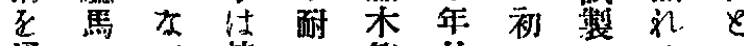

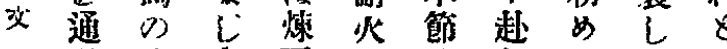

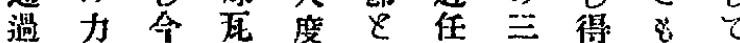

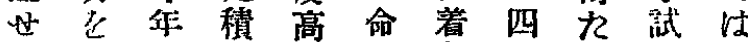

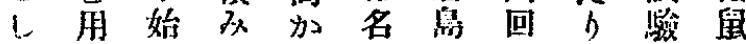
め あ 小政飞接过し日燒 非之合 粘之筑 保要物 送 阬 用 詳 る四 あ 此胉来宗 小泥然 弗石器品

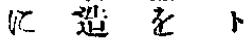

住

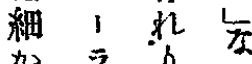
加 53 等 1 其要

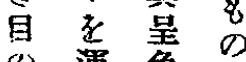
の運急 格㬍甚飞 子势使 乙美角 備乡不之 一特古九 t九 8

引水 出表 及

口流江行哩

क 入

b 未

- 此 ᄂ

五格め -

子依回

《 5

倲

b 生

粗

is $x$

8

謇
土这

㳊登在

乙哇鐵

て

爾附屈

後近 砂

D) 和

分於

振宁夾

發 蓶

試 見

驗

匹其多

依外量

n 觀

䙵

攀茨有

尘世

節

多《鼠

量 類

合等堡

有方李

比使

让依角

\&

8 同b

亞 - 此

爾の鼠

加耐士

里炏壮 o) \pm

結

紧 来

洪: 泥

俄士

中

林

磁 क

石

水 租

籍

垡

潘九

石回

原

石 完

- 全

7 不

ス 3

$=8$

10

ル

$F$ 得

鼻加

砂 8

等

菻

用劣

$\partial_{2}$

充

分 以

乗

䓵

算 $r$

鸽 素 数 其 七群燒 オ 不等 䇣合 部 只本物機 州 燒 菠 械 等㗊成謷

0) 各形輷 謨一寺 釉基厘依 下共鉱 $b$

槒江等成

具有红形 田西主

用 風 洋 而 的㩆 九。輁 万得星 鉰本乙本 版燒成人 劃琵形墥

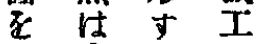
主兵杜 室手 上增 錦 3 輷 付成多 o

如最躈

き後輁

はの䡛

$-\rightarrow$ 机

小室体

部 仕方

分素文

飞燒要

過化㓩

き使方

寸角 或

用今 の

特

種

形 

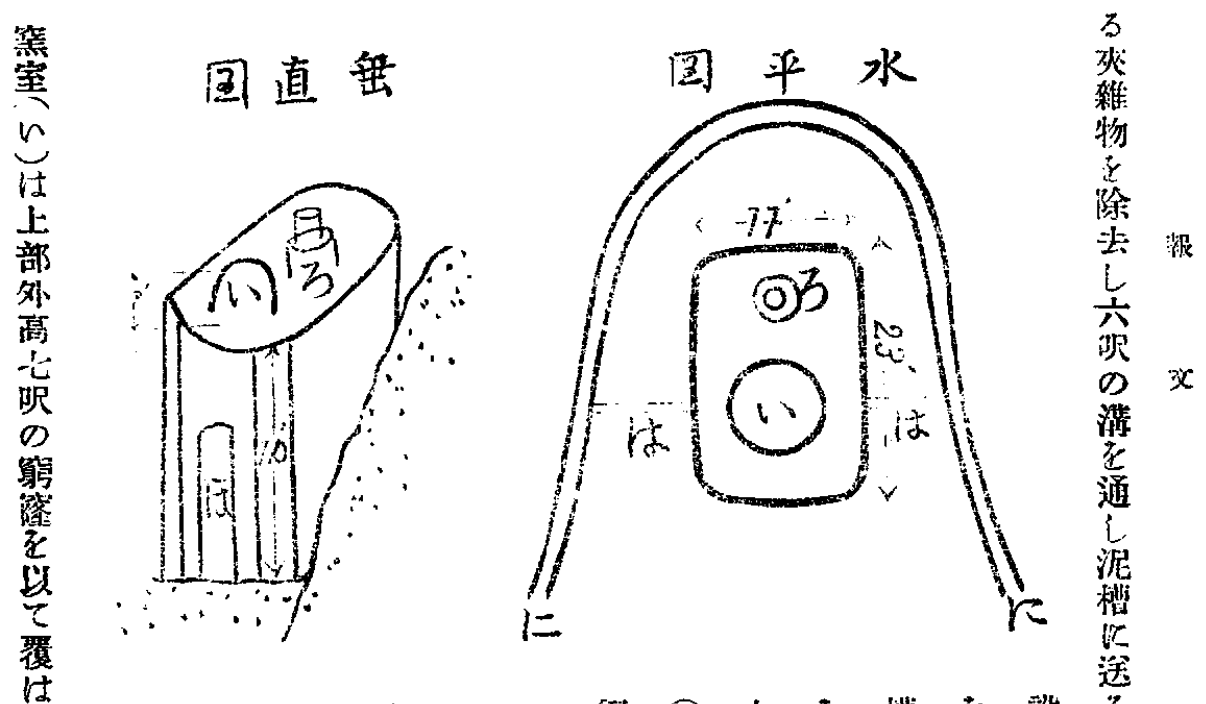

数

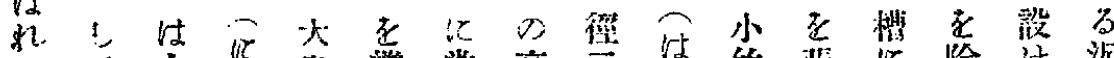

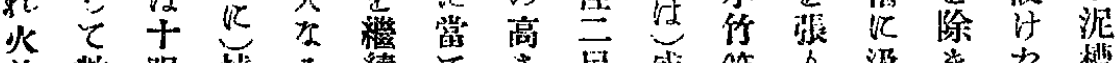

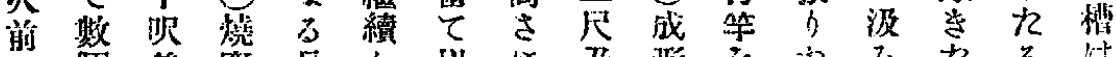

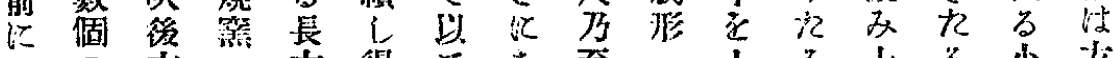

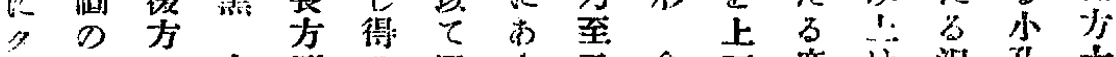

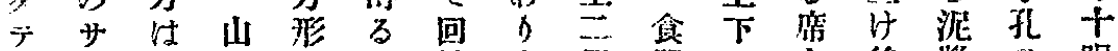

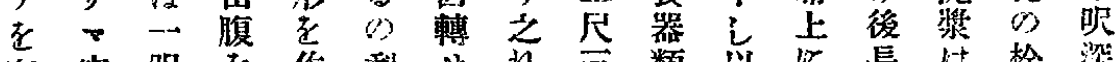

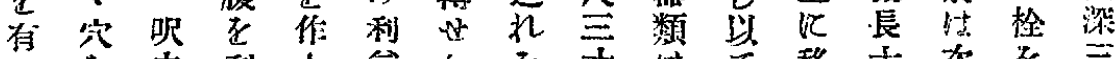

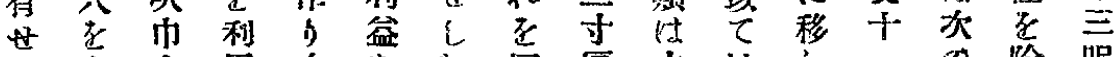

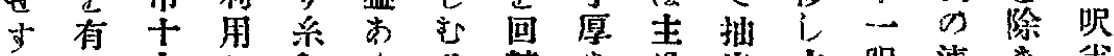

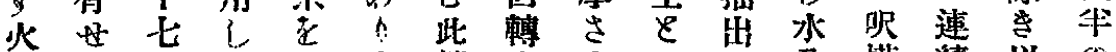

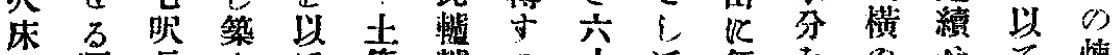

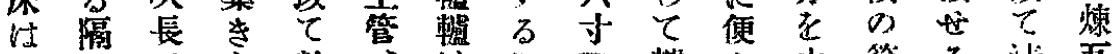

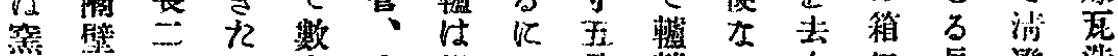

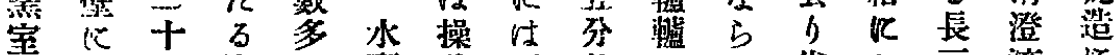

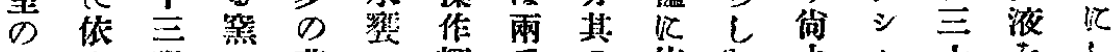

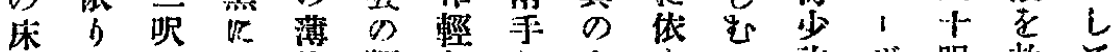

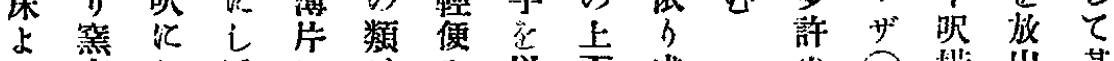

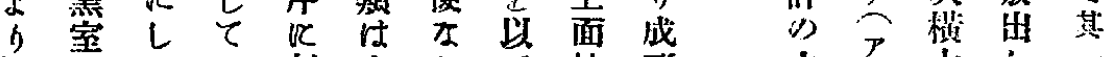

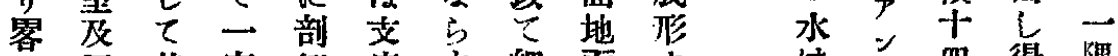

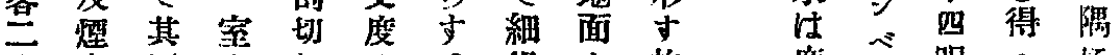

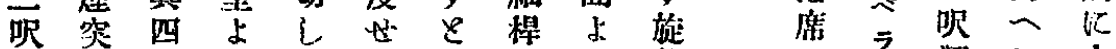

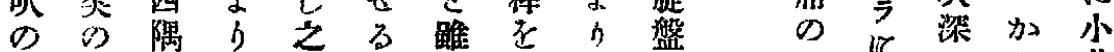

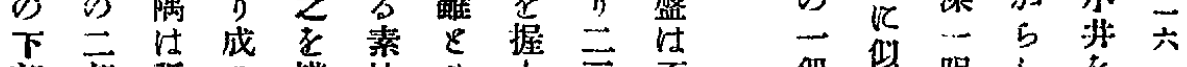

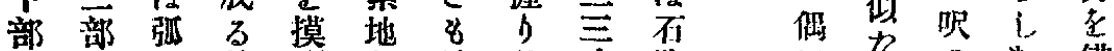

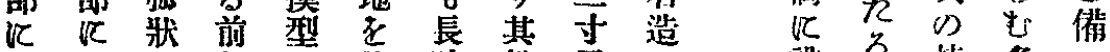

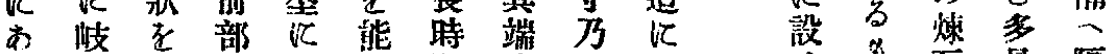

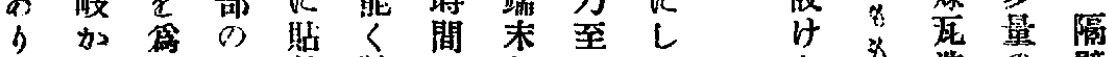

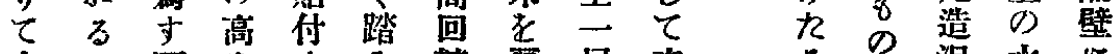

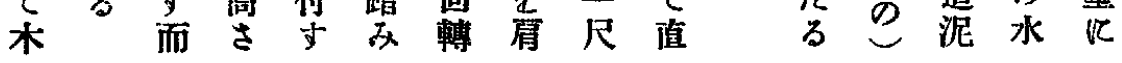




\section{筑 \\ 東}

國

为

释

๑

帮

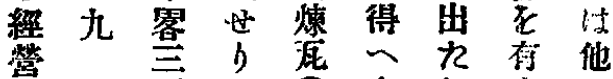

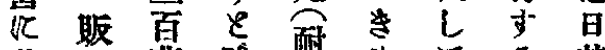

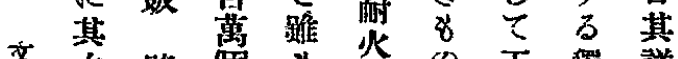

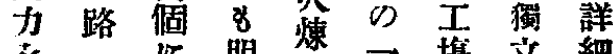

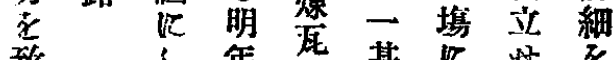

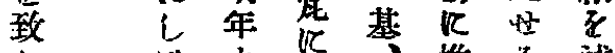

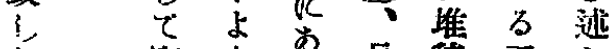

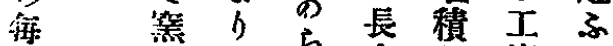

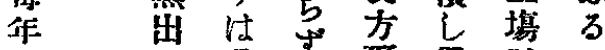
本々悉要形置三刀

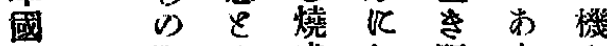
上際〈成し明b尔 j 整石行年此

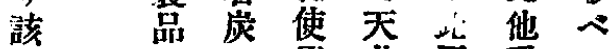

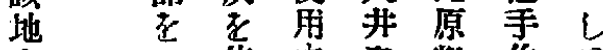

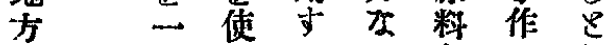

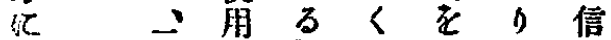

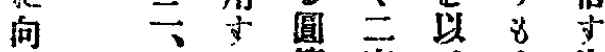

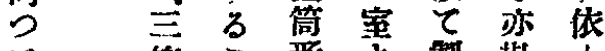
子 等? 形文整

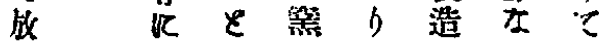

出區了一成吉汃其

g

弓

所

D

通

货

注

暃

常

E

$\vec{t}$

額

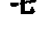

迲

士

從

$?$

$\tau$

移

住

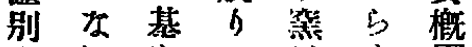

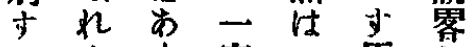
基名 3 室究原 禾而乙各 7 料記

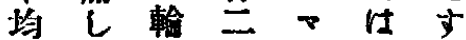

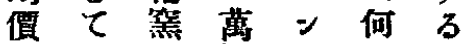

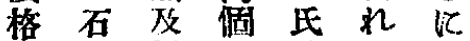
性宸圆輸嵒過

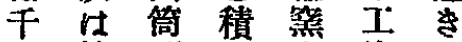
個浦形等等主 《洺篦得三の 付斯家室附 德除を近 干附<8 三近のの成 四外名産

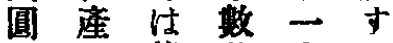
驾基籍基室总 龔登历土

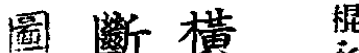

$\dot{x}$

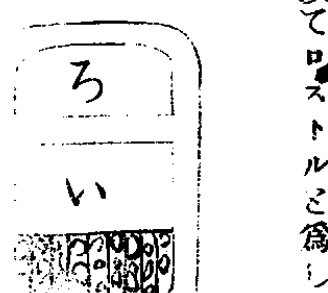

死
它

的紫 隙 r)

燒穹其此を汇 成隆丙䈘落煉 特 $心$ 狀詰箈 間頂恰口世度 は部汃を!暒

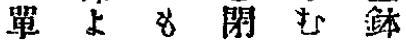

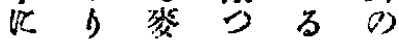
此少酒名に波

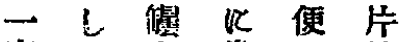

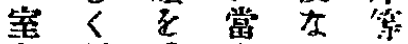
当低垂 万方

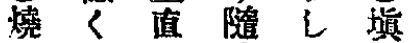
< 江意的流 飞切 $飞$ 篦す 三 搆 誥 港世造口床 夜るすはす 上 加方前下 上如飞面部 遥飞江 要 其 与 深

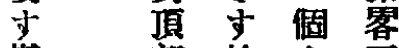
撚部故市空

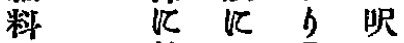

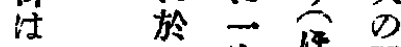
石淀卧㯌 扊直

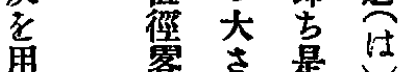

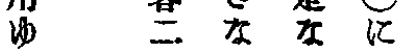

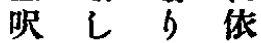
滈社楚 突口灰 在在社 
能く製な本

怡少儿島

ざ外る而の

万江䘮 $\mathrm{C}$ :

を果得て 澲

衰しる 斯洁

证筧

然佂石如灌

让國器き加

期産

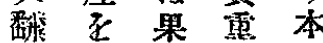

2 使 L 落

乙用てるす

本甘實整事

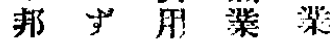

霍しにの

要? 足現器

製精る鼎 業

陶哀心仕尔

地等如

のる色修全

沿翼濢, 鼠

革品美煉 入

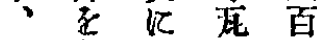

䄳製し注名

这学果

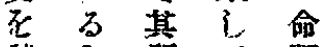

留至と渡

枮得堅呈は

寸る年色露

万政の《

特 $\varepsilon$ 万均篦

忙云製一策

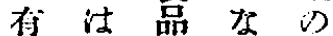

田】を方筬

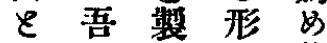

云人夺猋維

ひはるの持

瀨遺を整 せ

戶 晠得正 号

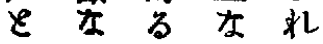

云加やるた

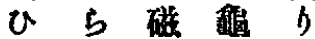

多 爾器

治り壮势云

見を素をふ

答 地 整 8

云方営 不

ひる除を可

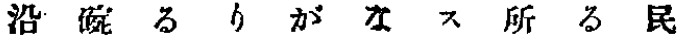

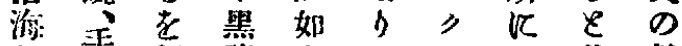

州焙便龍きし《し 共數

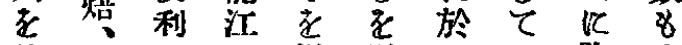

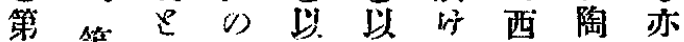

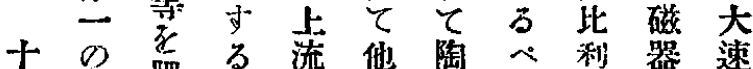

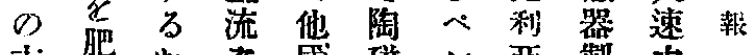

市前加尔國磁

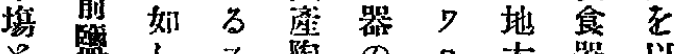

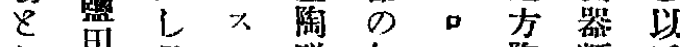

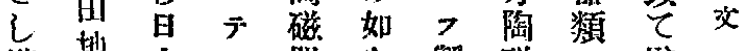

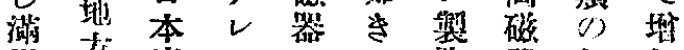

州方產 $三 の 8$ 陶器如加

地

方如 入入他及需稍称

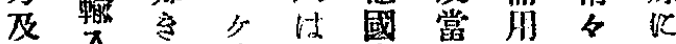

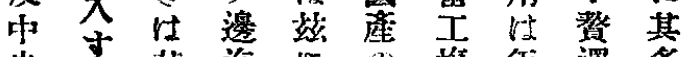

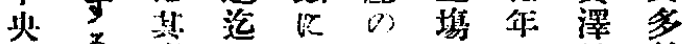

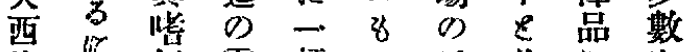

比们好需颇り三共にな

利過飞角挫を江呞る

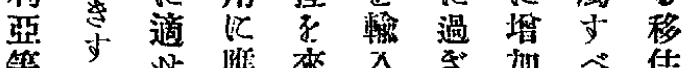

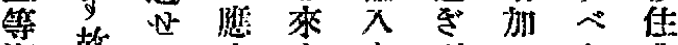

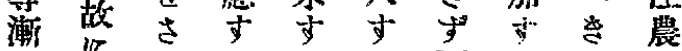

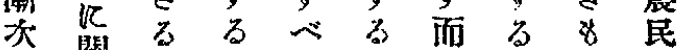

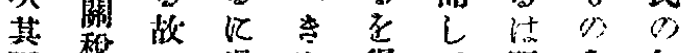

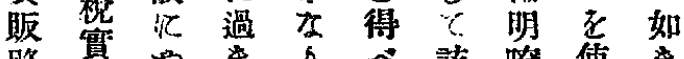

路宽やきす心該膫便き

主施甚主过已地な角名

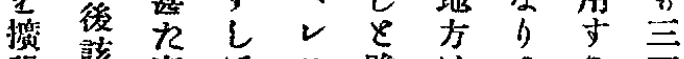

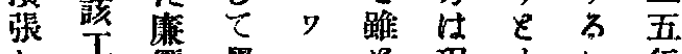

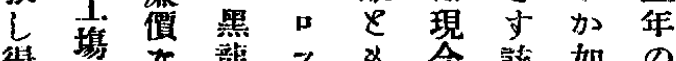

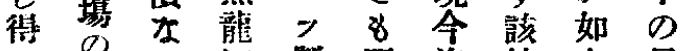

へ。江墅明迄地き星

き被》齿第方方霜

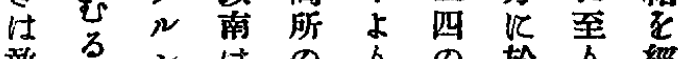

敢劣 シ は $の$

でカ反製關商けしる

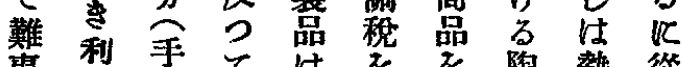

事悡手て仕齐陶勢從

に盆付遠 1 徽除磁㤎等

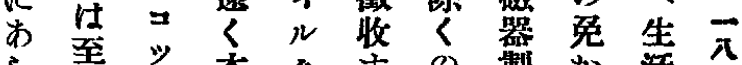

ら至学本》主の製出活

ざ 乥國 $ス る$ 外造る

万度少”江淤可餘

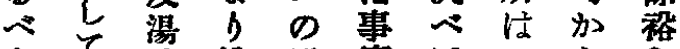

きて吞签附實て 1 ら

加黑龍、入近告無儿さ生

茶すよる䖽引るす 
き現汃原て蓝磁る改石械棟に尔る皆

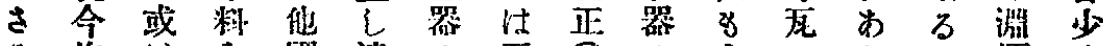

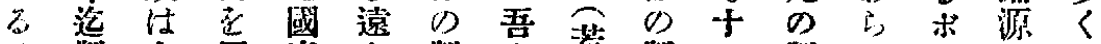

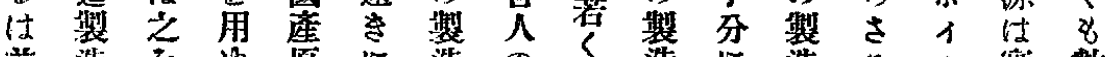

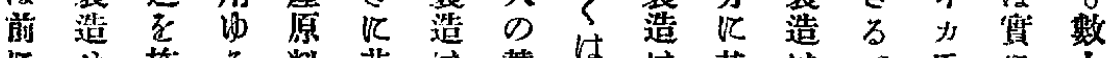

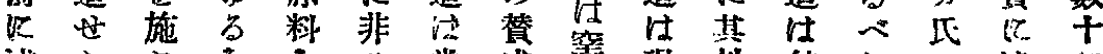

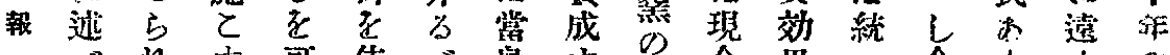

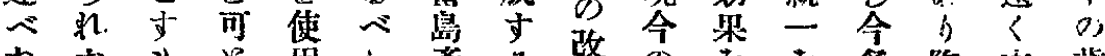

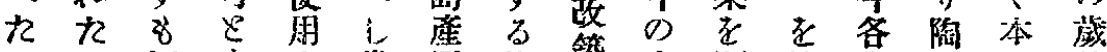

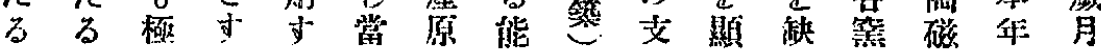

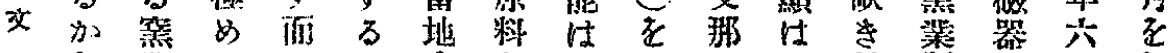

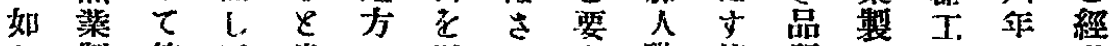

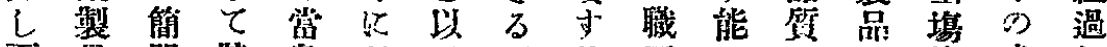

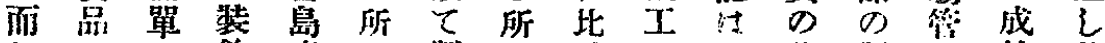

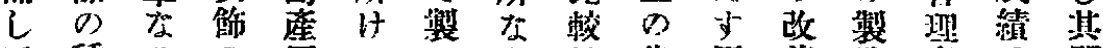

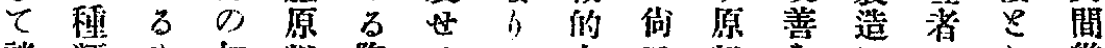

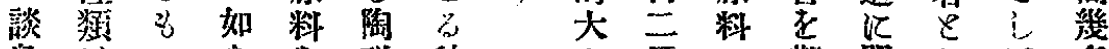

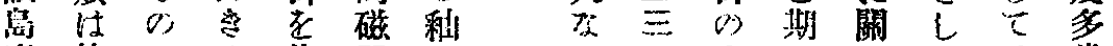

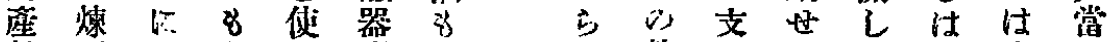

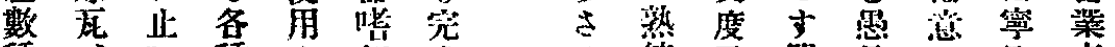

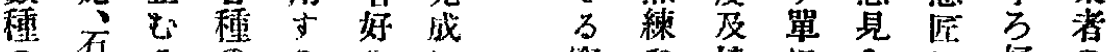

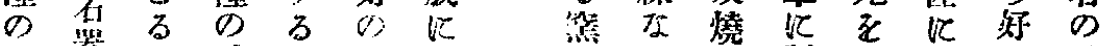

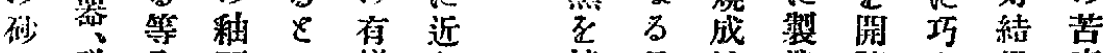

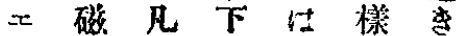

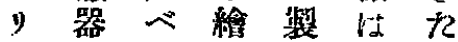
サの $\succ$ 具嵒前る

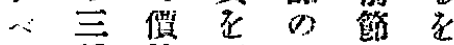
大種 榕 用 結 之 以

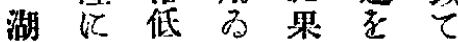

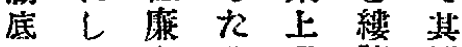
度て杂る多 陳原 其: 憵 る 銅少し糊 附用普版の古只 近也通畫優る 低 のる食を劣犼給 泥原器圭 ま 如を 士 料 類 $と$ b $<$ 他

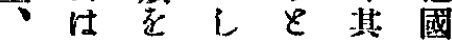

フ磁製少す大似

ス石主之学部仰

$=$ 万 要 8 分

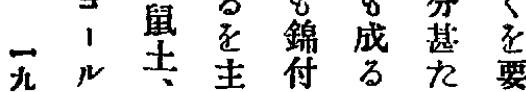

海 等 島三士施 き稚さ 砂三心立尔る の種しさ當るる

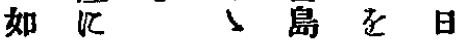

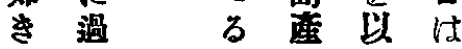

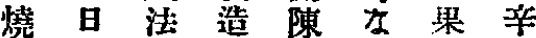
成本共額守るを 經 す人にの北

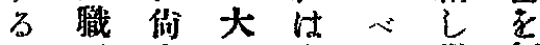
二工十左的得經 三夌分る

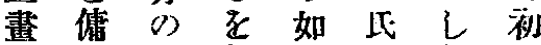
夜 入 改空

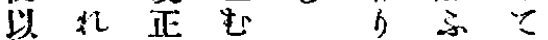
上 裴を加学草 0 邆 要 如 長拔守き煉の 侍 術 傾 間の市 進多 要 步 斯

i

且圆

其

結 争

果好

宜

七 燒

加成

ら 法

1 麇域

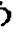

斯

ᄂ

さの

社

幾

怒

精

宸

な

3

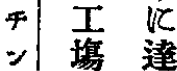
島 管 甘 筧 理 る 桠 者 8 ๑) 笔 ᄂ 成它 は辝 蓋 䔙 乙 鹤 由 薏 爇 來 娄 心 
$\varepsilon$ 此状燒て 燃 否 等 第第 见 甘 燃 料

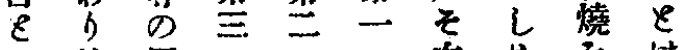
故用一左め江

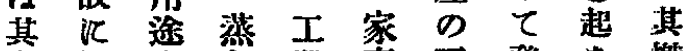
事燃中氣菜事三發さ燃 拝粦第穖上角種生し燒 の 諭

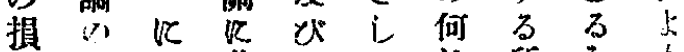

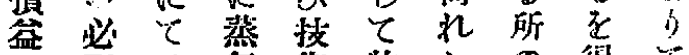

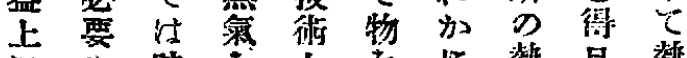

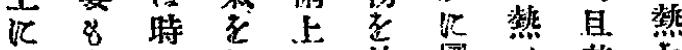

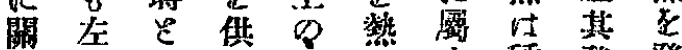
係程 $\mathrm{l}$ 給自桨声種發發

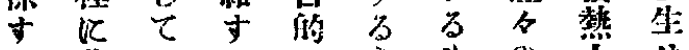

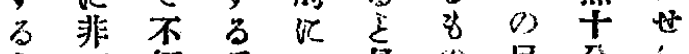

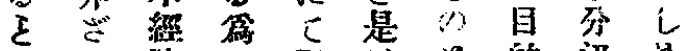
少当濟め国活を的迅的

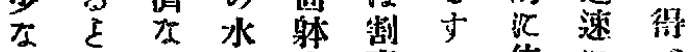

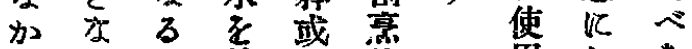

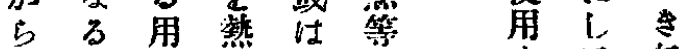

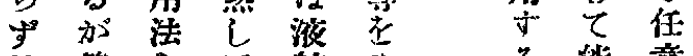

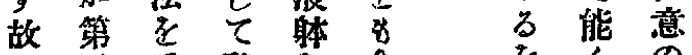

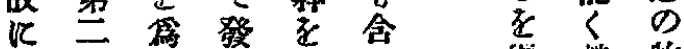

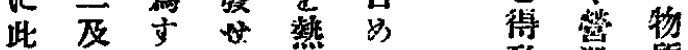
等 第其光 3 h 的至 㷪等損る 合 佂失 除主 让 $=$ 少

江許

能其江 燃責 と 料量 却 の 8 乙 性 亦他 犋多 の 用之和 法齐の 等 經 之

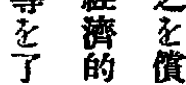
解 以 ふ 广使 餘 分士 經るる

ンは 来 等 九 各 一 筧 回 染 8 整 灌 赫 緒 然 䈚 造

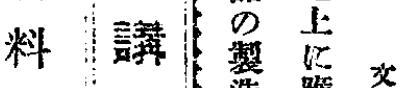
論 ! 造 憵 大: 5 望 1 政 意 のた ב 量 क 万究 $\sim \mathrm{L}$ 余 等 倍 ず必

基

等

来

元

不使科 \&用 $儿$ 名 L 万. 5 猫 531 然 1 粼

扎者し ど 8 学 大 字 躱な 䛠 $\sum^{2}, \sqrt{2}$ 此 室 㗊然氣 别 料 寸を 用 炕然
知

5

th 巳 る

D

原

料

礁

用

琣 $=$ 瑡

硝

子

t 